\title{
Phytochemical, Antidiabetic, and Cytoprotective Properties of Berberis aristata DC. Root Extracts
}

\author{
Manjari Mittal $^{*}, 1$, Vijay Juyal ${ }^{1}$ and Anita Singh ${ }^{2}$ \\ ${ }^{1}$ Uttarakhand Technical University, Dehradun, 248001 (Uttarakhand), India; ${ }^{2}$ Department of Pharmacy, Devasthali \\ Vidhyapeeth, Rudrapur, 263148 (Uttarakhand), India
}

\begin{abstract}
The present study was aimed to evaluate the phytochemical, antidiabetic, and cytoprotective properties of Berberis aristata DC. (Berberidaceae) root extracts. After phytochemical evaluation of various extracts of $B$. aristata roots, the ethanol extract was found to be rich in phytochemicals with the presence of alkaloid determined by the thin layer chromatography; hence ethanol extract was selected for further study. Administration of ethanol extract of B. aristata roots in diabetic rats showed dose dependent reduction in hyperglycemia. The levels of serum total cholesterol, triglyceride, AST (aspartate aminotransferase), ALT (alanine aminotransferase), serum creatinine and blood urea were significantly decreased in diabetic rats when compared with diabetic control rats.
\end{abstract}

Keywords: Alloxan, antidiabetic, Berberis aristata DC., cytoprotective, glimepiride, phytochemical.

\section{INTRODUCTION}

Diabetes is rapidly emerging as a global health problem which could reach pandemic levels by 2030 . The number of worldwide diabetes cases is projected to increase from 171 million in 2000 to 366 million in 2030. Diabetes mellitus (DM) is rapidly increasing in developing countries of the world, it is being recognized that the incidence and prevalence are increasing at an alarming rate in young person, particularly in obese children [1].

DM is one of the oldest common metabolic disorders that affect the whole body system. Several types of DM exist and result by a complex interaction of genes and drugs, gestational diabetes, environmental factors like stress and sedentary life-style choices. DM is the leading cause of end-stage renal disease, non-traumatic lower extremity amputations, and adult blindness. With increasing incidences worldwide, DM will likely continue to be a leading cause of morbidity and mortality for the foreseeable future [2].

From the ancient time, various ethnic and traditional plant medicines have been used to treat diabetes and some of them were clinically proven by various medicinal systems like Ayurveda and Chinese medicines. These herbal drugs were found to be effective in controlling blood glucose levels after thorough investigations and provide active hypoglycemic principles [3].

The world health organization (WHO) has also recommended the evaluation of the effectiveness for various plants' treatments of disease conditions where we lack safe modern drugs [4]. Plants have long been a principal source of drugs and now many of the available drugs have been

\footnotetext{
*Address Correspondence to this author at Uttarakhand Technical University, Dehradun, 248001, (Uttarakhand), India; Tel: +60166098757; +919411809626; E-mail: manjarig21@rediffmail.com
}

derived directly or indirectly from plants. More than 800 plants may possess anti-diabetic potential according to ethnobotanical information reports [5].

Berberis aristata DC. belongs to family Berberidaceae and widely distributed in evergreen regions of temperate and sub- tropical. Berberis has about 650 species worldwide, of which 54 have been reported from Indian Himalaya, especially in state of Himachal Pradesh. Berberis aristata, known as Daruhaldi, is a large deciduous shrub usually in 1.8-3.6 meter height. Its leaves are obovate or elliptic, entire, base gradually narrowed with reticulate nerves and glossy dark green color. Its flowers are numerous and stalked. Its roots are thick woody, yellowish brown, cylindrical, knotty and covered with a thin brittle bark [6] and have valuable isoquinoline alkaloid berberine. Berberis aristata is used in Ayurveda medicines from very long time. An important ayurvedic preparation Rashut is prepared by this plant [7]. Berberine has predominant clinical uses in bacterial diarrhoea, intestinal parasite infections, ocular trachoma infection [8], eye infection, skin diseases, jaundice, antifungal, antipyretic [9] and as antiarrhythmic, antiinflammatory, immunostimulative, antitumor [8], astringent, tonic, febrifuge, laxative and also for menorrhagia [10].

The objective for this study was to evaluate the phytochemical, antidiabetic, cytoprotective effect of $B$. aristata roots on diabetic rats.

\section{MATERIALS AND METHODOLOGY}

\section{Plant Material}

The roots of B. aristata were collected in November 2009 from higher regions of Mussoorie, Uttarakhand, India, and were identified and authenticated by botanist Dr. Veena at Forest Research Institute, Dehradun. A voucher specimen 
(voucher no. Dis/2010-Bot./4-12 herb) was deposited at Forest Research Institute Herbarium for future reference.

\section{Extraction}

The fresh roots were shade dried at room temperature (25 $\pm 2{ }^{\circ} \mathrm{C}$ ) and then ground to a coarse powder. The powdered roots were extracted successively with petroleum ether, benzene, chloroform, methanol, ethanol, and water in a soxhlet assembly. Each extract solution was concentrated under reduced pressure in rotor evaporator, the furnished concentrated extracts were stored in the air tight container.

\section{Phytochemical Screening}

The different solvent extracts of the roots of $B$. aristata were subjected to preliminary phytochemical screening for the identification of their chemical constituents using the method suggested by Harbone [11] as shown in Table $\mathbf{1}$.

\section{TLC Profile}

Thin layer chromatography (TLC) profile of the ethanol extract was done with the help of some selected solvent systems, detection reagents and wavelength as shown in Table 2 [12].

\section{Animal}

Male wistar albino rats (150-200 g, 6-8 week) were housed in spacious cage and allowed one week to adapt to their new environment. The animals were maintained in an environment of controlled temperature $\left(25 \pm 2{ }^{\circ} \mathrm{C}\right)$ under a 12 hr. light-dark cycle. For rats, standard rodent chow and water were provided throughout the experimental period. All animal procedures used were in strict accordance with the committee for the purpose of control and supervision of experiments on animals (CPCSEA) and all experimental protocols were approved by the institutional ethics committee.

\section{Induction of Diabetes}

Animals were made diabetic by a single intraperitoneal injection of alloxan monohydrate (Rolex chemical Limited, Mumbai). Experimental diabetes was induced by alloxan which was first weighed individually for each animal according to $120 \mathrm{mg} / \mathrm{kg}$ body weight (b. wt.) and then dissolved in sterile normal saline just prior to injection [13] and as diabetic control, standard and test groups respectively. After three days alloxan injection, rats with plasma glucose levels excess of $150 \mathrm{mg} / \mathrm{dl}$ were used in the study [14].

\section{Experimental Design}

Thirty male wistar rats were divided into five groups.

Group- I (Normal Control): Rats were given only vehicle (water) (diabetes free rats).

Group- II (Diabetic control): Rats were given alloxan monohydrate to induce diabetes (diabetic rats).

Group- III (Standard): Glimepiride (1mg/kg b. wt., Intas Pharmaceuticals Ltd.) was administered to alloxan monohydrate induced diabetic rats.

Table 1. Phytochemical Evaluation of Berberis aristata DC. Roots Extracts

\begin{tabular}{|c|c|c|c|c|c|}
\hline Tests & Pet. Ether & Chloroform & Methanol & Ethanol & Water \\
\hline Carbohydrate & -- & +++ & +++ & +++ & +++ \\
\hline Alkaloid & -- & -- & +++ & +++ & -- \\
\hline Tannins & $-\cdots$ & $-\cdots$ & +++ & +++ & --- \\
\hline Protein \& Amino acid & -- & +++ & +++ & -- & +++ \\
\hline Glycosides & -- & +++ & -- & -- & -- \\
\hline Phytosterols & -- & +++ & -- & +++ & +++ \\
\hline Flavonoid & --- & +++ & +++ & +++ & +++ \\
\hline Volatile oils & +++ & -- & -- & +++ & -- \\
\hline Fixed oils \& fats & +++ & -- & +++ & +++ & --- \\
\hline Saponin & --- & +++ & -- & -- & +++ \\
\hline $\mathrm{pH}(1 \%)$ & 7.6 & & & & \\
\hline
\end{tabular}

+++ positive result, - - - negative result

Table 2. TLC Profile of Ethanol Extract of Berberis aristata DC. Roots

\begin{tabular}{|c|c|c|}
\hline Solvent system & Extracts & Rf value \\
\hline Cyclohexane:Chloroform:Glacial acetic acid $(45: 45: 10)$ & Ethanol & $0.70,0.73$ \\
\hline Toluene:Ethylacetate:Diethylamine (70:20:10) & Ethanol & $0.61,0.67$ \\
\hline
\end{tabular}

Detection reagent: Dragendroffs reagent, 5\% sulphuric acid; Detection: UV $365 \mathrm{~nm}$. 


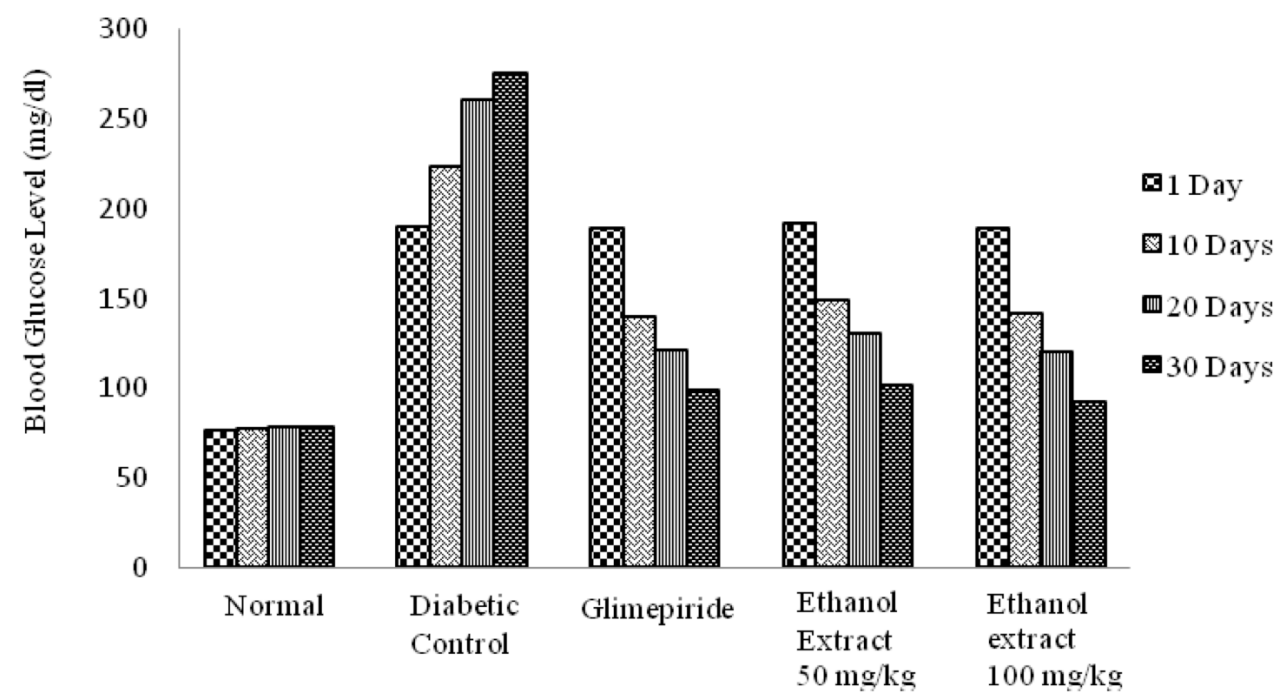

Fig. (1). Antidiabetic effect of ethanol extracts of Berberis aristata DC. roots.

Table 3. Antidiabetic Effect of Ethanol Extracts of Berberis aristata DC. Roots.

\begin{tabular}{|c|c|c|c|c|c|c|c|}
\hline Animal Groups & \multicolumn{7}{|c|}{ Blood Glucose (mg/dl) } \\
\hline Normal & $76.60 \pm 0.44$ & \multicolumn{2}{|c|}{$77.70 \pm 0.88$} & \multicolumn{2}{|c|}{$78.48 \pm 0.85$} & \multicolumn{2}{|c|}{$78.33 \pm 0.49$} \\
\hline Diabetic Control & $190.65 \pm 0.98$ & \multicolumn{2}{|c|}{$223.47 \pm 1.13$} & \multicolumn{2}{|c|}{$260.33 \pm 0.64$} & \multicolumn{2}{|c|}{$275.48 \pm 1.14$} \\
\hline $\begin{array}{c}\text { Glimepiride } \\
\text { (1 mg/kg Body wt.) }\end{array}$ & $189.17 \pm 0.28$ & \multicolumn{2}{|c|}{$140.52 \pm 0.83^{\mathrm{a}}$} & \multicolumn{2}{|c|}{$121.80 \pm 0.65^{\mathrm{a}}$} & \multicolumn{2}{|c|}{$99.42 \pm 0.34^{\mathrm{a}}$} \\
\hline $\begin{array}{c}\text { Ethanol Extract } \\
\text { (50 mg/kg Body wt.) }\end{array}$ & $192.32 \pm 0.69$ & $\begin{array}{c}149.67 \pm \\
0.65^{\mathrm{a}}\end{array}$ & $\downarrow 33.02 \%$ * & $\begin{array}{c}130.78 \pm \\
0.39^{\mathrm{a}}\end{array}$ & $\downarrow 49.76 \% *$ & $\begin{array}{c}101.90 \pm \\
0.34^{\mathrm{a}}\end{array}$ & $\downarrow 63.01 \%{ }^{*}$ \\
\hline $\begin{array}{c}\text { Ethanol Extract } \\
\text { (100 mg/kg Body wt.) }\end{array}$ & $189.35 \pm 1.01$ & $\begin{array}{c}141.50 \pm \\
0.51^{\mathrm{a}}\end{array}$ & $\downarrow 36.08 \%$ * & $\begin{array}{c}119.90 \pm \\
0.39^{\mathrm{a}}\end{array}$ & $\downarrow 53.94 \% *$ & $\begin{array}{c}92.90 \pm \\
0.26^{\mathrm{a}, \mathrm{b}}\end{array}$ & $\downarrow 66.27 \%{ }^{*}$ \\
\hline
\end{tabular}

Values are given in $\mathrm{mg} / \mathrm{dl}$ as mean \pm S.E.M. for groups of six animals; ${ }^{\text {a }}$ statistically significant Vs Diabetic control $(p<0.05)$; ${ }^{b}$ statistically significant Vs Glimepiride $(p<0.05)$; one way ANOVA Tukey's test. *Percentage. Reduction when compared with diabetic control.

Group- IV (Test 1): Ethanol extract of B. aristata roots $(50 \mathrm{mg} / \mathrm{kg} \mathrm{b}$. wt.) was administered to alloxan monohydrate induced diabetic rats.

Group- V (Test 2): Ethanol extract of B. aristata roots (100 mg/kg b. wt.) was administered to alloxan monohydrate induced diabetic rats

Treatment with the standard drug glimepiride and the ethanol extracts were started $72 \mathrm{hr}$. after alloxan injection. Blood samples were collected at $1^{\text {st }}, 10,20$, and $30^{\text {th }}$ day intervals through retro-orbital route. Fasting blood glucose estimation was done on the $1^{\text {st }}, 10,20$, and $30^{\text {th }}$ day of the study.

\section{Estimation of Biochemical Parameter}

Blood samples from animals were collected on $1^{\text {st }}$ and $30^{\text {th }}$ day of study for serum total cholesterol, serum triglycerides, and serum creatinine, blood urea, AST and ALT. All these values were estimated by commercially available kits (Span diagnostic Pvt. Ltd. Surat, India).

\section{Statistical Analysis}

All the values of body weight, blood sugar and biochemical estimations were expressed as mean \pm S.E.M. (Standard Error Mean) and analyzed with SigmaStat ${ }^{\circledR}$ software for ANOVA \& Tukey's test. Differences between groups were considered significant at $p<0.05$ levels.

\section{RESULTS AND DISCUSSION}

\section{Phytochemical Evaluation}

This study found after phytochemical screening that the ethanol extract of $B$. aristata roots contains maximum phytoconstituents with the presence of carbohydrate, alkaloid, tannins, phytosterols, flavonoid, volatile oils, fixed oils and fats as shown in the Table 1. On the basis of phvtochemical screening the ethanol extract was selected for 
Table 4. Cytoprotective and Antilipidemic Effect Ethanol Extract of Berberis aristata DC. Roots

\begin{tabular}{|c|c|c|c|c|}
\hline Parameters & Normal & $\begin{array}{c}\text { Diabetic } \\
\text { control }\end{array}$ & $\begin{array}{c}\text { B.aristata Extract } \\
\mathbf{( 5 0 ~} \mathbf{~ m g / k g b o d y ~ w t . )}\end{array}$ & $\begin{array}{c}\text { B.aristata } \text { Extract } \\
\mathbf{( 1 0 0} \mathbf{~ m g} / \mathbf{k g b o d y} \mathbf{~ w t})\end{array}$ \\
\hline \hline Blood urea (mg/dl) & $31.80 \pm 0.39$ & $95.77 \pm 1.07$ & $71.46 \pm 1.27^{\mathrm{a}}$ & $59.85 \pm 0.45^{\mathrm{a}}$ \\
\hline S.Creatinine (mg/dl) & $0.48 \pm 0.01$ & $1.48 \pm 0.01$ & $0.77 \pm 0.01^{\mathrm{a}}$ & $0.58 \pm 0.001^{\mathrm{a}}$ \\
\hline AST (U/L) & $37.40 \pm 0.56$ & $99.15 \pm 1.01$ & $39.13 \pm 0.59^{\mathrm{a}}$ & $34.90 \pm 0.44^{\mathrm{a}}$ \\
\hline ALT (U/L) & $47.46 \pm 0.65$ & $107.52 \pm 0.54$ & $70.70 \pm 0.78^{\mathrm{a}}$ & $51.68 \pm 0.34^{\mathrm{a}}$ \\
\hline Total Cholesterol (mg/dl) & $66.40 \pm 0.61$ & $183.22 \pm 0.45$ & $68.86 \pm 0.38^{\mathrm{a}}$ & $55.43 \pm 0.33^{\mathrm{a}}$ \\
\hline Triglycerides (mg/dl) & $87.42 \pm 1.39$ & $150.70 \pm 1.51$ & $64.27 \pm 0.60^{\mathrm{a}}$ & $58.26 \pm 0.30^{\mathrm{a}}$ \\
\hline
\end{tabular}

Effect of ethanol extract of B. aristata roots on serum profile in alloxan induced diabetic wistar rats after 30 days of treatment. Values are given as mean \pm S.E.M. for groups of six

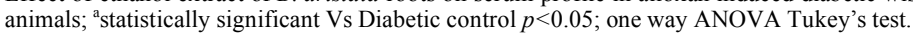

screening the ethanol extract was selected for further study. It was stated [7] that the roots of B. aristata contain mainly the alkaloid berberine. The presence of alkaloid was confirmed by TLC comparing the Rf value and yellow color fluorescence with the reference [12] at same experimental condition as shown in Table 2.

\section{Antidiabetic Effect}

The ethanol roots extract of B. aristata at the dose of 50 and $100 \mathrm{mg} / \mathrm{kg}$ body wt. exhibited significant antidiabetic property when compared with diabetic control $(p<0.05)$. These significant antidiabetic effects were shown by both the extracts on $1^{\text {st }}$ day, $10^{\text {th }}$ day, $20^{\text {th }}$ day and $30^{\text {th }}$ day of the study (Fig. 1 and Table 3). The results of previous studies also indicated the antidiabetic effects of $B$. aristata [15-17], but in this study we revealed that the ethanol root extract of B. aristata at the dose of $100 \mathrm{mg} / \mathrm{kg} \mathrm{b}$. wt. On $30^{\text {th }}$ day was showed significant antidiabetic effects as it was found more effective. Administration of ethanol extracts $(50 \mathrm{mg}$ and $100 \mathrm{mg} / \mathrm{kg} \mathrm{b}$. wt.) of B. aristata roots in diabetic rats showed dose dependent and statistically significant $(p<0.05)$ reduction in hyperglycemia. The $63.01 \%$ reduction in blood glucose level was observed at $50 \mathrm{mg} / \mathrm{kg} \mathrm{b}$. wt. and $66.27 \%$ at $100 \mathrm{mg} / \mathrm{kg}$ b. wt. when compared with diabetic control. The reason for this significant antidiabetic effect of $B$. aristata may be due to the dipeptidyl peptidase-IV (DPP-IV) inhibition [18].

\section{Antihyperlipidemic Effect}

Diabetes is associated with hyperlipidemia [15]. The levels of total cholesterol and triglycerides were raised in diabetic rats after 30 days of study when compared with normal control group. The levels of total cholesterol and triglycerides were controlled significantly in the groups treated with $50 \mathrm{mg} / \mathrm{kg}$ and $100 \mathrm{mg} / \mathrm{kg} \mathrm{b}$. wt. dose of the ethanol extract when compared with diabetic control. These results showed the potential of $B$. aristata in significantly controlling the diabetes induced hyperlipedemia (Table 4).

\section{Cytoprotective Effect}

The levels of aminotransferases, such as alanine aminotransferase (ALT) and aspartate aminotransferase (AST) were found to be increased in diabetic rats after 30 days. It was reported that the patients with type 2 diabetes patients have a higher incidence of liver function test abnormalities than normal individuals. Mild chronic elevations of transaminases AST and ALT are often reflect underlying insulin resistance [19]. AST and ALT levels were decreased very significantly $(p<0.05)$ in groups treated with $50 \mathrm{mg} / \mathrm{kg}$ and $100 \mathrm{mg} / \mathrm{kg} \mathrm{b}$. wt. dose of ethanol extract when compared with diabetic control rats (Table 4). The possible reason for decrease in ALT levels is achieving tighter blood glucose levels with antidiabetic agents [19].

Diabetes nephropathy is common complication associated with diabetes. As seen in our study after 30 days the levels of serum creatinine and blood urea were increased in diabetic control indicating the kidney damage. The levels of serum creatinine and blood urea were controlled significantly $(p<0.05)$ in the groups treated with $50 \mathrm{mg} / \mathrm{kg}$ and $100 \mathrm{mg} / \mathrm{kg}$ b. wt. dose of ethanol extract when compared with diabetic control (Table 4). The results showed the dose dependent effect in controlling serum creatinine and blood urea.

\section{CONCLUSION}

Our study revealed that ethanol extract of B. aristata has antidiabetic activity because it has significant dose dependent reduction effect on the blood glucose levels of diabetic rats. This study also revealed that this ethanol extract decreases the levels of some biochemical parameters such as AST, ALT, total cholesterol, triglyceride, creatinine, and blood urea, which always be found to be increased in diabetic rats. Therefore, the ethanol root extract of $B$. aristata would be beneficial for the patients with diabetes because of its antidiabetic and cytoprotective activities.

\section{ABBREVIATIONS}
ALT
$=$ Alanine aminotransferase
AST
$=$ Aspartate aminotransferase
CPCSEA
$=$ Committee for the purpose of control and supervision of experiments on animals
$\mathrm{DM}=$ Diabetes mellitus
TLC = Thin layer chromatography
WHO = World Health Organization 


\section{REFERENCES}

[1] Sukandar, E. Y.; Permana, H.; Adnyana, I. K.; Sigit, J. I.; Ilyas, R. A.; Hasimun, P.; Mardiyah, D. Clinical study of turmeric (Curcuma longa L.) and garlic (Allium sativum L.) extracts as antihyperglycemic and antihyperlipidemic agent in type-2 diabetes-dyslipidemia patients. Int. J. Pharmacol., 2010, 6(4), 456-463.

[2] Braunwald, E.; Fauci, A. S; Kasper, D. L.; Hauser, S. L.; Longo, D. L.; Jameson, J. L. Harrison's Principles of Internal Medicine, 15th ed.; McGraw Hill Medical: New York, 2001.

[3] Li, W. L.; Zheng, H. C.; Bukuru, J.; De Kimpe, N. Natural medicines used the traditional Chinese medical system for therapy of diabetes mellitus. J. Ethnopharmacol., 2004, 92(1), 1-21.

[4] Rang, H. P.; Dale, M. M.; Ritter, J. M.; Flower, R. J. Rang and Dale's Pharmacology, 6th ed.; Churchill Livingstone: London, 2007.

[5] Mohammad, Y. M. I. Clinical evaluation of antidiabetic activity of Trigonella seeds and Aegle marmelos leaves. World Appl. Sci. J., 2009, 7(10), 1231-1234.

[6] Malik, A. R.; Ali, M.; Sharma, K. R. Vegetative propagation of Berberis aristata DC. An endangered Himalayan shrub. J .Med. Plants. Res., 2008, 2(12), 374-377.

[7] Sharma, K.; Bairwa, R.; Chauhan, N.; Shrivastava, B.; Saini, N. K. Berberis aristata A review article. Int. J. Res. Ayur. Pharm., 2011, 2(2), 383-388.

[8] Zhou, J.; Zhou, S.; Tang, J.; Zhang, K.; Guang, L.; Huang ,Y.; Xu, Y.;Ying ,Y.; Zhang, L.; Li, D. Protective effect of berberine on beta cells in streptozotocin and high carbohydrate/ high fat diet induced diabetic rats. Eur. J. Pharmacol., 2009, 606, 262-268.

[9] Shahid, M.; Rahim, T.; Shahzad, A.; Tajuddin, L. A.; Fatima, T.; Rashid, M.; Raza, A.; Mustafa, S. Ethanobotanical studies on Berberis aristata DC. roots extracts. Afr. J. Biot., 2009, 8(4), 556-563.
[10] Evans, W. C. Trease and Evans Pharmacognosy, 15th rep ed.; Elsevier: London, 2006.

[11] Harbone, J. B.; Baxter, H. H. Phytochemical Dictionary: A Handbook of Bioactive Compounds from Plants, Taylor and Francis: Washington, 1993.

[12] Wagner, H.; Bladt, S. Plant Drug Analysis (Thin Layer Chromatography Atlas), 2nd ed.; Springer Verlag: New York, 1984.

[13] Guruvayoorappan, C.; Sudha, G. Phytopharmacological evaluation of byesukar for hypoglycaemic activity and its effect on lipid profile and hepatic enzymes of glucose metabolism in diabetic rats. Ann. Hepatol., 2008, 7(4), 358-363.

[14] Rathnaker, U. P.; Kaderbhai, H. S.; Pemminathi, S.; Shenoy, A.; Gopalakrishna, H N.; Siddique, F. Hypoglycemic activity of a polyherbal product in alloxan induced diabetic rats. Drug Invent. Today, 2011, 3(3), 1-2

[15] Upwar, N. K.; Patel, R.; Waseem, N.; Mahobia, N.K. Hypoglycemic effect of methanol extract of Berberis aristata D.C stem on normal and streptozotocin induced diabetic rats. Int. J. Pharm. Pharm. Sci., 2011, 3(1), 222-224.

[16] Semwal, B. C.; Gupta, J.; Singh, S.; Kumar, Y.; Girl, M. Antihyperglycaemic activity of root of Berberis aristata D.C. in alloxan induced diabetic rats. Int. J. Green Pharm., 2009, 3, 259-262.

[17] Kakkar, P.; Singh, J. Antihyperglycaemic and antioxidant effect of Berberis aristata roots extract and its role in regulating carbohydrate metabolism in diabetic rats. J. Ethnopharmacol., 2009, 123(1), 22-26.

[18] Thirumurgan, K.; Chakrabarti, R.; Singh, B.; Prakrith, N.; Varghese, N.; Shihabudeen, M. S. Dipeptidyl peptidase-IV inhibitory activity of Berberis aristata. J. Nat. Prod., 2011, 4, 158-163.

[19] Harris, E. H. Elevation liver function tests in type 2 diabetes. Clin. Diabetes, 2005, 23(3), 115-119.

(C) Mittal et al.; Licensee Bentham Open.

This is an open access article licensed under the terms of the Creative Commons Attribution Non-Commercial License (http://creativecommons.org/ licenses/ by-nc/3.0/) which permits unrestricted, non-commercial use, distribution and reproduction in any medium, provided the work is properly cited. 